\title{
UPAYA MENINGKATKAN AKTIVITAS DAN HASIL BELAJAR PERPAJAKAN MAHAISSWA DENGAN MENGGUNAKAN STRTAGEI PEMBELAJARAN MODEL KOOPERATIF GRUP INVESTIGATION
}

\author{
Oleh: \\ Dearlina Sinaga ${ }^{1)}$ dan Surya Darma Pardede ${ }^{2)}$ \\ Universitas Nommensen, Medan ${ }^{1,2}$
}

E-Mail :

$\underline{\text { dr.dearlina@gmail.com }}^{1),} \underline{\text { suryadarmapardede0@ gmail.com }}^{2)}$

\begin{abstract}
This study aims at improving the activities and learning outcomes of student taxation by applying the learning strategy of the Investigation Group (IG).This type of research is classroom action research (CAR) which has been carried out in two cycles. The research strategy used is the learning structure of the Investigation Group (IG) with the research design of the Two Groups; Pre-test and post-test design. The results of observations that have been conducted show that student learning activities were improved, namely cycle I there were 5 students or $20.84 \%$ for active and very active criteria while in the second cycle of meeting I there are 14 students or as many as $58.33 \%$ for active and very active criteria, then on cycle IIon meeting II, there are 17 students or as many as $70.83 \%$ for active and very active criteria. This shows an increase in student activity from the first and second cycle. Whereas the results of student learning tests that were carried out obtained data on the average value of learning outcomes in the pre-test with an average score of 49.16 or as many as $16.66 \%$. In the post-test cycle I the researchers applied the learning structure the Investigation Group (IG), there was an increase in scores with an average of 67.08 or as many as $62.5 \%$ of the total population while the average value in the second cycle increased to 74.16 or as many as $79.165 \%$. Based on the results of the above research it can be concluded that applying the learning strategy the Investigation Group (IG) can improve student activities and learning outcomes.
\end{abstract}

Keywords: Learning Activities, Learning Outcomes, Learning Strategies Group Investigation $(I G)$

\section{PENDAHULUAN}

Sesuai dengan Peraturan Presiden

Republik Indonesia Nomor 8 Tahun 2012

tentang Kerangka Kualifikasi Nasional Indonesia, Peraturan Menteri Pendidikan dan Kebudayaan Republik Indonesia Nomor 73 Tahun 2013 tentang Penerapan
Kerangka Kualifikasi Nasional Indonesia Bidang Pendidikan Tinggi, dan sesuai dengan Peraturan Menteri Riset, Teknologi dan Pendidikan Tinggi Republik Indonesia Nomor 44 Tahun 2015 tentang Standar Nasional Pendidikan Tinggi, sehingga menggharuskan para 
akademisi untuk dapat menyesuaikan sesuai dengan standar pendidikan yang diterntukan oleh Pemerintah melalui Menteri Pendidikan dan Kebudayaan.

Pembelajaran di Perguruan Tinggi merupakan suatu proses interaksi (hubungan timbal balik) antara dosen dan mahasiswa di dukung unsur-unsur yang ada di dalamnya. Tujuan, materi pembelajaran, sarana prasarana,kondisi belajar,media pembelajaran,lingkungan belajar, metode pembelajaran, serta evaluasi unsur-unsur pembelajaran yang memperngaruhi keberhasilan proses belajar mengajar serta meningkatkan hasil belajar mahasiswa. Proses belajar mengajar di pengaruhi dari faktor dalam dan luar mahasiswa, diantaranya model pembelajaran. Penggunaan model yang tepat sangat mempengaruhi keberhasilan proses pembelajaran.

Mata kuliah perpajakan merupakan displin ilmu yang dinamis, yang dapat berubah setiap saat, yang disesuaikan dengan amademen yang dilakukan oleh yang berwenang untuk memenuhi suatu transaksi atau untuk mencapai tujuan social dan kebutuhan ekonomi. Dengan perkembangan perekonomian akan berdampak terhadap displin ilmu perpajakan. Hal ini disebabkan bahwa displin ilmu perpajakan merupakan perpaduan yang kompleks antara berbagai displin ilmu seperti ekonomi,akuntansi, hukum, ilmu politik,dan keuangan Negara.
Mengingat perpaduan yang komples tersebut sehingga sebagian besar mahasiswa merasa kesulitan untuk memahami inti permasalah perpajakan sedangkan mata kuliah ini adalah mata kuliah inti yang dapat meningkatakan wawasan dan profesionalisme mahasiswa. Maka dalam pelajaran akuntansi perpajakan diharapkan mahasiswa dapat memahami materi yang disampaikan oleh fasilitator.

Salah satu upaya untuk meningkatkan kompetensi belajar mahasiswa dan kualitas pemahaman mahasiswa terhadap perkuliahan yaitu dengan cara membelajarkan mahasiswa, dalam arti dosen harus mampu menuntun mahasiswa agar berperan aktif. Untuk dapat menguasai materi ajar tersebut maka diperlukan strategi tertentu sehingga mahasiswa mampu secara mandiri menguasai materi ajar tersebut. Masih kurangnya mahasiswa dalam memahami praktek akuntansi perpajakan hal ini akan berdampak terhadap aktivitas dan hasil belajar mahasiswa.

Oleh karena itu maka aktivitas belajar mahasiswa sangat mempengaruhi hasil belajar saat pembelajaran berlangsung. .aktivitas belajar. Peneliti memilih model pembelajaran kooperatif Group Investigation (GI) untuk diterapkan dalam kegiatan pembelajaran akuntansi perpajakan. Metode GI menghendaki mahasiswa bekerja sama saling bantu 
dalam kelompok dan memilih topik-topik yang akan dipelajari. mahasiswa dalam kelompok bekerja sama menganalisis masalah, kemudian melalui keputusan bersama atau kelompok dipilih suatu pemecahan masalah. Selanjutnya tiap-tiap kelompok mempresentasikan atau menampilkan penemuan mereka di hadapan kelas (Slavin, 2008).

Berdasarkan uraian di atas, penulis tertarik mengadakan penelitian dengan judul "Upaya Meningkatkan Aktivitas dan Hasil Belajar Akuntansi Perpajakan Dengan Menggunakan Strategi Pembelajaran Group Investigation (GI) Prodi Pendidikan Ekonomi TA 2018
Jenis penelitian ini adalah penelitian tindakan kelas (classroom action research). Menurut Arikunto, dkk (2012:16) adapun langah- langkah penelitian tindakan kelas dilakukan dalam dua siklus dan didalam penelitian ini terdapat empat tahapan yang lazim dilalui yaitu: (1) perencanaan (planning), (2) pelaksanaan (action), (3) pengamatan (observation), (4) Refleksi (reflecting).

Berikut ini digambarkan model pada penelitian tindakan kelas yang akan digunakan sebagai siklus dalam penelitian:

\section{METODE PELAKSANAAN}

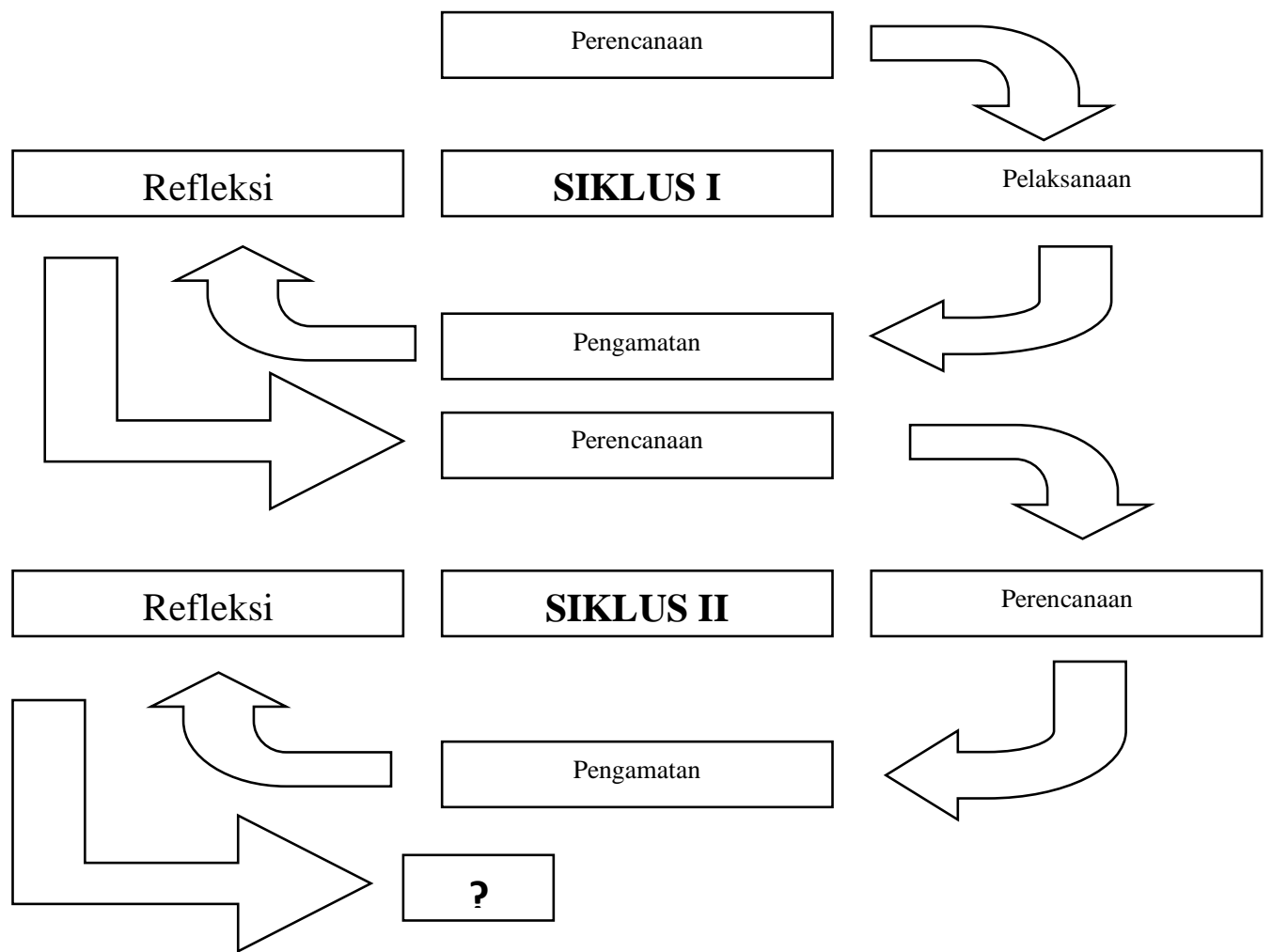

Gambar 1. Model Penelitian Tindakan kelas Sumber : Arikunto, dkk (2012: 16) 
Tahap-tahap kegiatan analisis data dapat dipertanggung jawabkan kualitatif adalah mereduksi data, kebenarannya.

menyajikan data dan penarikan kesimpulan.

1. Mereduksi Data

Mereduksi data adalah proses kegiatan menyeleksi, memfokuskan dan menyederhanakan semua data yang telah diperoleh, memulai dari awal pengumpulan data sampai penyusunan laporan penelitian.

2. Penyajian Data

Penyajian data dilakukan dalam rangka mengorganisasikan hasil reduksi dengan cara menyusun secara naratif sekumpulan informasi yang telah diperolah dari hasil reduksi, sehingga dapat memberikan kemungkinan penarikan kesimpulan dan penarikan tindakan. Penyajian data bisa dilakukan dalam bentuk tabel (persentase), diagram dan bagan.

3. Penarikan Kesimpulan

Penarikan kesimpulan adalah proses penampilan intisari terhadap hasil penafsiran dan evaluasi. Kegiatan ini mencakup pencarian makna data serta memberi penjelasan. Selanjutnya dilakukan kegiatan verifikasi, yaitu menguji kebenaran, kekokohan dan kecocokan makna-makna yang muncul dari data. Varifikasi data dimaksudkan untuk mengevaluasi segala informasi yang telah didapatkan dari infarman, sehingga akan didapatkan suatu data yang valid dan berkualitas serta hasil dari data tersebut data yang digunakan dalam menganalisa data kuantitatif yang diperoleh dari hasil tes belajar mahasiswa dan menentukan persentase ketuntasan belajar siswa dengan menggunakan rumus sebagai berikut :

a. Daya Serap

Analisa data untuk mengetahui daya serap masing-masing siswa digunakan rumus sebagai berikut :

$D S=\frac{\text { Skor angka diperoleh siswa }}{\text { Jumlah skor maksimal }} \times 100 \%$

Arikunto (2008 : 45 )

Keterangan :

DS = Daya Serap

Dengan kriteria :

$0 \% \leq \mathrm{DS}<70 \% \quad$ Siswa belum tuntas belajar

$70 \% \leq \mathrm{DS} \leq 100 \%$ Siswa telah tuntas dalam belajar.

b. Ketuntasan Belajar Klasikal

Selanjutnya dapat diketahui ketuntasan secara keseluruhan dengan rumus sebagai berikut:

$$
\mathrm{D}=\frac{X}{N} \times 100 \%
$$

(Arikunto 2008)

\section{Keterangan :}

$\mathrm{D}=$ persentase kelas yang telah mencapai daya serap $\geq 70 \%$

$\mathrm{X}=$ jumlah siswa yang mencapai daya serap $\geq 70 \%$

$\mathrm{N}=$ jumlah siswa subjek penelitian 
Pedoman yang digunakan untuk melihat tingkat penguasaan dapat dilihat sebagai berikut :

\begin{tabular}{|l|l|}
\hline Ketuntasan & $\begin{array}{l}\text { Kriteria } \\
\text { Kemampuan }\end{array}$ \\
\hline $90 \%-100 \%$ & Sangat Baik \\
\hline $80 \%-89 \%$ & Baik \\
\hline $70 \%-79 \%$ & Cukup \\
\hline $60 \%-69 \%$ & Kurang \\
\hline $0 \%-59 \%$ & Sangat kurang \\
\hline
\end{tabular}

Berdasarkan kriteria ketuntasan belajar, jika di kelas tersebut telah mencapai nilai minimal $70 \%$ siswa yang telah mencapai daya serap atau nilai $\geq 70$ maka ketuntasan secara keseluruhan terpenuhi.

Untuk pengetahuan peningkatan aktivitas belajar siswa dapat dilihat dari hasil lembaran observasi aktivitas siswa selama proses belajar mengajar berlangsung, hasil observasi keaktifan belajar siswa, respon siswa terhadap pengelolaan pembelajaran dianalisis dengan deskriptif persentase secara kuantitatif.

\section{HASIL DAN PEMBAHASAN}

Penerapan model pembelajaran kooperatif tipe Group Investigation (GI) ini bertujuan untuk meningkatkan Aktivitas perkuliahan Perpajakan Keberhasilan tindakan ini dapat dilihat dari hasil pengamatan proses pembelajaran. Apabila hasil yang didapatkan telah sesuai dengan kriteria keberhasilan tindakan yang ditentukan sehingga tindakan ini dinyatakan berhasil.

Keberhasilan penerapan model pembelajaran kooperatif tipe Group Investigation (GI) untuk meningkatkan Aktivitas Belajar Akuntansi mahasiswa dilihat dari beberapa kriteria. Kriteria tersebut adalah peningkatan persentase Aktivitas Belajar Akuntansi dari siklus I ke siklus II, ketercapaian persentase Aktivitas Belajar Akuntansi secara individu dengan kategori Sangat Tinggi dan Tinggi lebih dari 70\%, serta ketercapaian persentase Aktivitas Belajar

Tabel 1

Perbandingan Aktivitas Individual Siklus I,II dan III

\begin{tabular}{|c|c|c|c|c|c|c|c|c|c|c|}
\hline \multirow[t]{2}{*}{ SIKLUS } & \multicolumn{2}{|c|}{ Mencatat materi } & \multicolumn{2}{|c|}{$\begin{array}{l}\text { Kerjasama dalam } \\
\text { kelompok }\end{array}$} & \multicolumn{2}{|c|}{$\begin{array}{c}\text { Mengeluarkan } \\
\text { pendapat/ } \\
\text { bertanya }\end{array}$} & \multicolumn{2}{|c|}{$\begin{array}{l}\text { Menjawab } \\
\text { pertanyaan }\end{array}$} & \multicolumn{2}{|c|}{$\begin{array}{l}\text { Partisipasi } \\
\text { dalam } \\
\text { pembuatan } \\
\text { laporan dan } \\
\text { presentasi }\end{array}$} \\
\hline & Skor & Persentase & Skor & Persentase & Skor & $\begin{array}{c}\text { Persenta } \\
\text { se }\end{array}$ & Skor & $\begin{array}{c}\text { Persen } \\
\text { tase }\end{array}$ & Skor & $\begin{array}{c}\text { Persent } \\
\text { ase }\end{array}$ \\
\hline I & 32 & $61,54 \%$ & 38 & $73,08 \%$ & 26 & $50.00 \%$ & 27 & $\begin{array}{c}51.92 \\
\%\end{array}$ & 42 & $80.77 \%$ \\
\hline II & 37 & $71.15 \%$ & 49 & $94.23 \%$ & 38 & $73.08 \%$ & 37 & $\begin{array}{c}71.15 \\
\%\end{array}$ & 46 & $88.46 \%$ \\
\hline III & 39 & $75,00 \%$ & 49 & $94,23 \%$ & 38 & $73,08 \%$ & 39 & $\begin{array}{c}75,00 \\
\%\end{array}$ & 46 & $88,46 \%$ \\
\hline
\end{tabular}


Tabel 2

Perbandingan Aktivitas Individual Siklus I,II dan III

\begin{tabular}{|c|c|c|c|c|c|c|c|c|c|c|}
\hline Siklus & \multicolumn{2}{|c|}{ Sangat aktif } & \multicolumn{2}{|c|}{ Aktif } & \multicolumn{2}{c|}{ Cukup aktif } & \multicolumn{2}{c|}{ Kurang aktif } & \multicolumn{2}{c|}{ Tidak aktif } \\
\hline & $\begin{array}{c}\text { Jlh } \\
\text { siswa }\end{array}$ & $\%$ & $\begin{array}{c}\text { Jlh } \\
\text { siswa }\end{array}$ & $\%$ & $\begin{array}{c}\text { Jlh } \\
\text { siswa }\end{array}$ & $\%$ & $\begin{array}{c}\text { Jlh } \\
\text { siswa }\end{array}$ & $\%$ & $\begin{array}{c}\text { Jlh } \\
\text { siswa }\end{array}$ & $\%$ \\
\hline I & 0 & $0.00 \%$ & 5 & $19.23 \%$ & 3 & $11.54 \%$ & 6 & $\begin{array}{c}23.08 \\
\%\end{array}$ & 12 & $46 \%$ \\
\hline II & 7 & $26.92 \%$ & 12 & $46.15 \%$ & 6 & $23.08 \%$ & 2 & $\begin{array}{c}7.69 \\
\%\end{array}$ & 0 & $0 \%$ \\
\hline III & 10 & $38.46 \%$ & 8 & $30.77 \%$ & 6 & $23.08 \%$ & 2 & $\begin{array}{c}7.69 \\
\%\end{array}$ & 0 & $0 \%$ \\
\hline
\end{tabular}

Berdasarkan tabel di atas, terlihat adanya peningkatan Aktivitas perkuliahan materi perpajakan secara keseluruhan dari siklus I,II dan III. Berdasarkan penilaian berdasarkan observasi adalah Persentase perkuliahan materi perpajakan pada siklus I menunjukkan rata-rata $63,46 \%$ dan penilaian berdasarkan observasi per individu adalah 26,92\%. Hal ini berarti Aktivitas perkuliahan materi perpajakan pada siklus I belum sesuai dengan yang diharapkan.

Aktivitas perkuliahan materi perpajakan pada siklus II penilaian berdasarkan observasi adalah Persentase perkuliahan materi perpajakan pada siklus II menunjukkan rata-rata $78,46 \%$ dan penilaian berdasarkan observasi per individu adalah $57,69 \%$ Hal ini menunjukkan adanya peningkatan persentase Aktivitas perkuliahan materi perpajakan dari siklus I ke siklus II. Berdasarkan penilaian observasi mengalami peningkatan sebesar $15 \%$ dan penilaian obsevasi pribadi mengalami kenaikan sebesar $30.77 \%$. dari persentase penilaian berdasarkan observasi sudah mencapai sudah standart yaitu > 75\% akan tetapi penilaian altivitas perkuliahan berdasarkan individu masih $<70 \%$ yaitu $57,69 \%$. Sehingga perlu dilakukan siklus ke III

Aktivitas perkuliahan materi perpajakan pada siklus III penilaian berdasarkan observasi adalah Persentase perkuliahan materi perpajakan pada siklus III menunjukkan rata-rata $81,15 \%$ dan penilaian berdasarkan observasi per individu adalah $73,08 \%$ Hal ini menunjukkan adanya peningkatan persentase Aktivitas perkuliahan materi perpajakan dari siklus II ke siklus III. Berdasarkan penilaian observasi mengalami peningkatan sebesar 2,69\% dan penilaian obsevasi pribadi mengalami kenaikan sebesar $15,39 \%$. dari persentase penilaian berdasarkan observasi sudah mencapai standart yaitu > 75\% akan tetapi penilaian altivitas perkuliahan berdasarkan individu masih $>70 \%$ yaitu 57,69\%. Persentase Aktivitas Belajar Akuntansi pada siklus III telah mencapai hasil yang diharapkan yaitu lebih dari $75 \%$.

Peningkatan hasil belajar mahasiswa matakuliah perpajakan berdasarkan hasil postest dengan penilaian ketuntasan nilai minimum yaitu $70 \%$ 


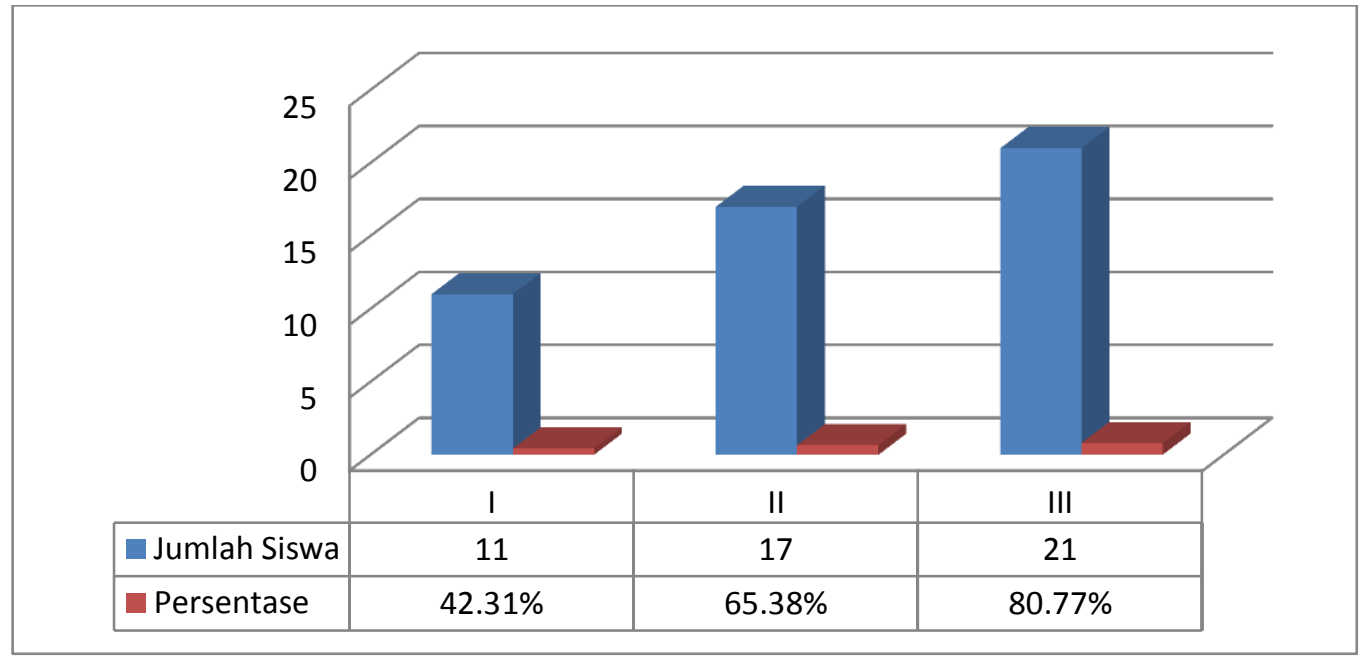

Gambar

2 penngkatan ketuntasan belajar

Persentase hasil
Sesuai

dengan

indikator

sbelajar mahasiswa Tuntas pada siklus I, II, III. Berdasarkan gambar di atas bahwa pada siklus I nilai mahasiswa yang > 70 adalah sebesar 11 orang atau $42,31 \%$ dan siklus ke II dari siklus I mengalami peningkatan yaitu 17 orang atau $65,38 \%$ atau mengalami kenaikan sebesar $23.07 \%$. siklus ke III mengalami peningkatan nilai ketuntasan minimum dari siklus ke II yaitu 21 orang atau $80.77 \%$ atau mengalami kenaikan sebesar 15,39\%.

Untuk menghitung ketuntasan secara keseluruhan atau klasikal digunakan rumus sebagai berikut:

Maka ketuntasan klasikal siklus I,II, III adalah sebagai berikut :

$\begin{aligned} \text { Siklus I } & =\frac{11}{26} \times 100 \% \\ & =42.30 \% \\ \text { Siklus II } & =\frac{17}{26} \times 100 \% \\ & =65.38 \% \\ \text { Siklus III } & =\frac{21}{26} \times 100 \% \\ & =80.76 \%\end{aligned}$

keberhasilan tindakan yang telah ditentukan, persentase Aktivitas Perkuliahan mata kuliah Perpajakan dari siklus I ke siklus II mengalami peningkatan $23.08 \%$. Siklus III mengalami peningkatan sebesar $15,38 \%$ dari siklus II. Adanya peningkatan hasil belajar mahasiswa dengan adanya peningkatan hasil belajar mahasiswa pada siklus I,II dan III

Ketercapaian persentase Aktivitas perkuliahan secara observasi dengan kategori Sangat Tinggi dan Tinggi mencapai lebih dari 75\%, serta ketercapaian persentase penilaian Aktivitas Perkuliahan mata kuliah individu mahasiswa mencapai lebih dari $70 \%$.

Sesuai dengan ketutasan klasikal maka siklus III lebih meningkat hasil belajar mahasiswa sebesar Dengan demikian, dapat dinyatakan dengan menggunakan strategi pembelajaran model kooperatif tipe Group Investigation (GI) dapat meningkatkan Perpajakan berdasarkan observasi 
aktivitas dan hasil belajar Mahasiswa semester III Grup A yang mengambil mata kuliah Perpajakan. Hal ini sesuai dengan pendapat Slavin (2015: 215) bahwa perencanaan kelompok dalam penerapan Group Investigation dapat mendorong keterlibatan maksimal para mahasiswa.

\section{KESIMPULAN}

Berdasarkan hasil temuan dalam refleksievaluasi, selanjutnya dapat ditarik simpulan dari penelitian ini bahwa :

1. Melalui prosedur yang konstruktif maka metode Grup Investigastion dapat meningkatkan kemampuan belajar mandiri mahasiswa jurusan Pendidikan Ekonomi pada mata kuliah akuntansi perpajakan. Prosedur yang harus dilakukan agar penggunaan metode Grup Investigastion efektif dapat meningkatkan kemampuan belajar mandiri adalah sebagai berikut : Mahasiswa dipahamkan dengan apa dan bagaimana metode metode Grup Investigastion diterapkan dalam pembelajaran yang berpusat pada mahasiswa. Mahasiswa diberikan tugas dengan menggunakan segala sumber belajar secara kooperatif. Pada bagian akhir pembelajaran, dosen harus menyampaikan koreksi dan refleksi atas proses dan isi pembelajaran.

2. Selain itu penggunaan metode metode Grup Investigastion pada pembelajaran akuntansi perpajakan berdampak positif terhadap perilaku dosen, suasana kelas dan perilaku mahasiswa. Dosen tidak lagi menjadi dictator of learning yang mendominasi pembelajaran dengan metode pembelajaran ekspositorik, tetapi berubah fungsi menjadi seorang fasilitator, motivator dan salah satu sumber belajar yang mampu mendorong proses belajar menjadi belajar berpusat pada mahasiswa serta dapat meningkatkan motivasi dan kemandirian belajar mahasiswa. Suasana kelas menjadi lebih aktifkreatif, dimana mahasiswa secara bertanggungjawab telah menyadari tugas utamanya adalah belajar dalam mencapai kompetensi tertentu, dan mampu membangun sendiri pengetahuan dan perilaku belajarnya dengan meningkatkan sikap perilaku belajar mandiri, serta meningkatkan jalinan kerja kooperatif dengan mahasiswa dan dosen. Sehingga orientasi pembelajaran tidak lagi berpusat pada dosen tatapi menjadi berpusat pada mahasiswa. Perilaku mahasiswa tidak lagi menunjukkan sikap tergantung kepada keberadaan dosen, tetapi dapat belajar mandiri. Mereka aktif mencari ilmu pengetahuan, dapat belajar secara terencana, memiliki kepercayaan diri, kritis dalam belajar dan memiliki self inforcement.

\section{DAFTAR PUSTAKA}

\author{
Arikunto.2014.ProsedurPenelitian \\ SuatuPendekatanPraktik, \\ Jakarta: Rineka Cipta \\ Djamarah.2013.StrategiBelajarMengajar, \\ Jakarta: PT RINEKA CIPTA.
}


ErnaRahmawati:"PengaruhPenerapanStrat egiGuided Teaching Terhadap MotivasiBelajarMatematikaSis waKelas VIII di SMP Negeri 3 Majalengka"

Frans Warren Sitanggang"Pengaruh Model PembelajaranGuided Teaching TerhadapHasilBelajarA kuntansiSiswadiKelas XII IPS SMA RK Deli Murni Deli Tua T.A 2016/2017".

Istarani.2015.EnsiklopediPendidikan, Medan:LARISPA.2012.58 Model PembelajaranInovatif, Medan: CV.ISCOM.

Sanjaya Wina. 2006. StrategiPembelajara nBerorientasiStandarProses Pendidikan, Jakarta:Kencana
Sudjana. 2016. MetodaStatistika, Bandung: Alfabeta.

Sudjana Nana.2014.PenilaanHasil Proses BelajarMengajar,Bandung: PT RemajaRosdakarya.

Sugiyono.2010.MetodePenelitianPendidik an,Bandung:Alfabeta.

Slameto. 2010. BelajardanFaktor-Faktor yang Mempengaruhinya, Jakarta: RinekaCipta.

Trianto. 2010. Mendesain Model PembelajaranInovatif-Progresif, Jakarta:

Kencana.

ZainiHisyam. 2008. Strategipembelajaranaktif,Yogyakarta : CTSP 